\title{
ON THE INITIATION OF THE WALKER CIRCULATION DURING 1982/1983 ENSO EVENT
}

\section{JOSÉ AUGUSTO PAIXÃO VEIGA ${ }^{1}$, VADLAMUDI BRAHMANANDA RAO² E SÉRGIO HENRIQUE FRANCHITO $^{2}$}

\author{
${ }^{1}$ Universidade do Estado do Amazonas - (UEA) AM, Brasil \\ ${ }^{2}$ Instituto Nacional de Pesquisas Espaciais - (INPE) SP, Brasil \\ jveiga@uea.edu.br, vadlamudi.rao@cptec.inpe.br, sergio.franchito@cptec.inpe.br
}

Received December 2007 - Accepted November 2008

\begin{abstract}
The GEOS-1 data from multiyear reanalysis are using. An altered Walker Circulation is initiated by the rising motion created over the warm ocean surface on the eastern Pacific. This occurred during the major El Niño event of 1982-1983. To compensate the rising motion, a sinking motion is generated over western Pacific completing the formation of the altered Walker Circulation. Thus, the initiation of the altered Walker Circulation is by the sea surface gradient as originally envisioned by Bjerknes.

Keywords: Walker Circulation, El Niño, ENSO, Thermodynamics

RESUMO: INICIAÇÃO DA CIRCULAÇÃO DE WALKER DURANTE O EVENTO DE ENOS DE $1982 / 1983$

Utilizando-se dados de reanálises do GEOS-1, observa-se que durante o El Niño de 1982-1983 a circulação de Walker anômala iniciou-se devido ao movimento ascendente gerado pelas águas superficiais quentes no Pacífico leste. Para compensar o movimento ascendente, subsidência de ar é gerada sobre o Pacífico oeste de forma a completar a circulação de Walker anômala. Assim, o início da circulação de Walker anômala ocorreu devido ao gradiente superficial sobre o mar tal como sugerido por Bjerknes.

Palavras-chaves: Circulação de Walker, ENOS, balanço de calor
\end{abstract}

\section{INTRODUCTION}

In his seminal paper Bjerknes (1969) called the circulation in the equatorial plane with rising motion on the western Pacific and sinking motion on the eastern Pacific as the Walker circulation. Regarding the generation of the Walker circulation, Bjerknes (1969) suggested that it is driven by the gradient of the Sea Surface Temperature (SST) along and south of the equator on the Pacific. He surmised that above the cold water belt in the eastern Pacific the air cannot join to the ascending motion in the Hadley circulation. Instead, the equatorial air flows westward to the western Pacific where it is supplied with moisture and heat from relatively warm water. This air can take part in the large-scale moist adiabatic ascent. In this picture of the Walker circulation it is implicitly assumed that the source of precipitation, which drives the circulation is the local evaporation associated with warm SST. However, Cornejo-Garrido and Stone (1977) showed through heat balance study of the Walker circulation that in the regions where the condensation is maximum, the evaporation is minimum. This shows the importance of moisture convergence rather than local evaporation for the precipitation. This is confirmed by Rao et al. (1998) and Veiga et al. (2005). Nevertheless, the Bjerknes hypothesis of the importance of SST gradients might still be invoked as an initiating mechanism for the Walker circulation. The best situation to test the Bjerknes hypothesis as an initiating mechanism is probably during the major El Niño events when the normal Walker circulation changes to anomalous circulation with major changes in the rising and sinking branches of the Walker circulation cells.

Yano et al. (2002) made a diagnosis of the mean tropical atmospheric circulation associated with large-scale SST 
gradients. They suggested that to a first order, the strength of the circulation is maintained by the descent rate in nonconvective region generated by the radiative cooling. Then the ascending motion occurs because of the mass continuity. The implication for a steady-state Walker circulation is that the ascending motion is a slave to the descending motion. While this may be true for a time mean-state, the initiation of Walker circulation can be the ascending motion provoked by the SST gradients. The purpose of the present work is to suggest that the initiation of altered Walker circulation during a major El Niño event is by the ascending motion over the warm pool in eastern Pacific Ocean. While, the descending motion is a response to the ascending motion, a situation opposite to that suggested by Yano et al.
(2002) for the steady-state Walker circulation. In this study we have chosen the major El Niño event of 1982-1983.

\section{DATA SOURCE AND METHODOLOGY}

We have used two datasets of distinct origin. First, the major data used in this study are the Goddard Earth Observing System-1 (GEOS-1) multiyear assimilation reanalysis gridded 2 degrees latitude X 2.5 degrees longitude (ftp://daac.gsfc.nasa. gov) for the 1982 and 1983 years. The mean (climatology) is calculated from 1981 to 1993 . More details about the GEOS-1 reanalysis can be found in Schubert et al. (1993) and Takacs et al. (1994). We use monthly mean data of air temperature (T),
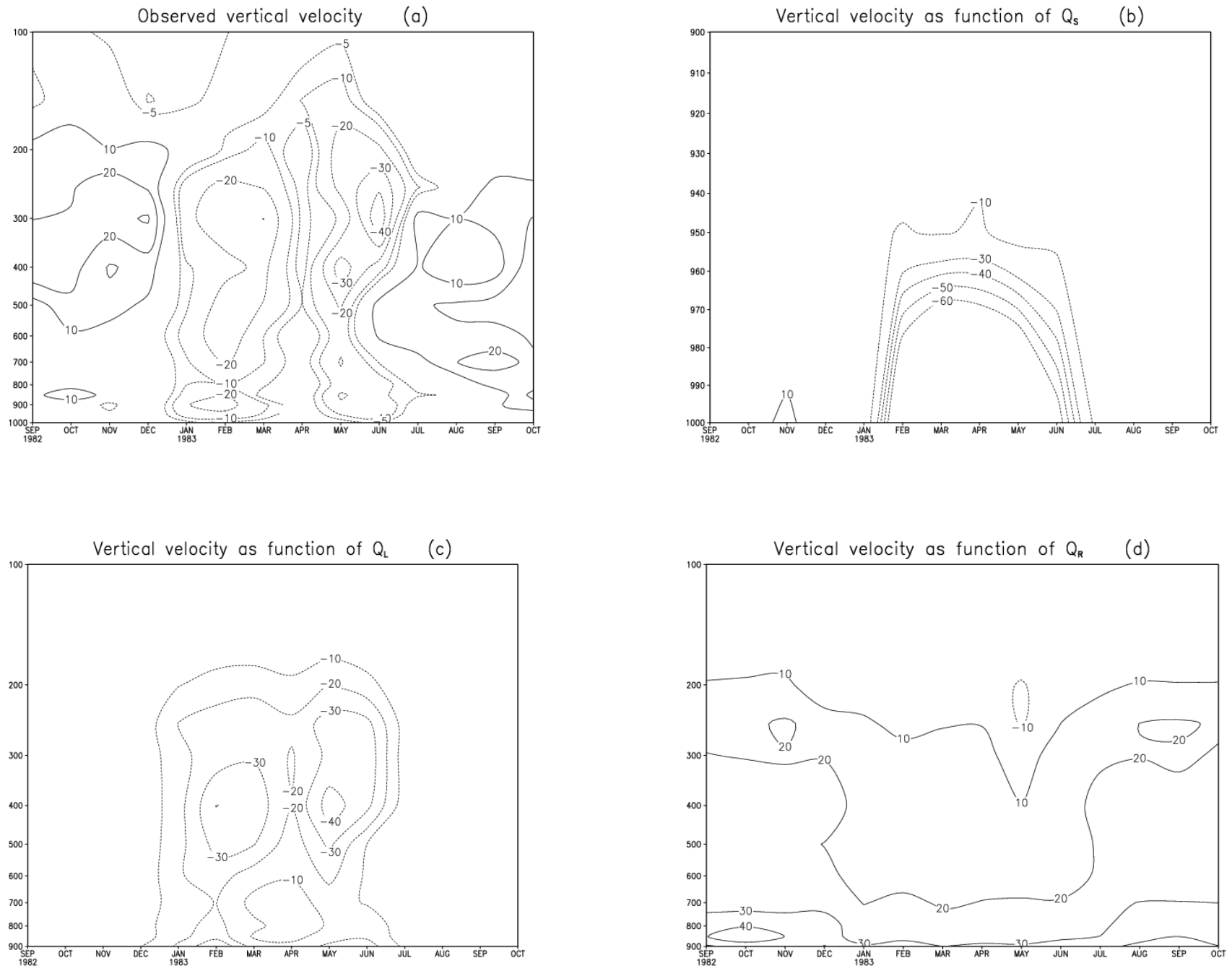

Figure - 1 Time mean vertical motions in the Walker Circulation at equator and $100^{\circ} \mathrm{W}$ : vertical velocity from GEOS-1 data (a), vertical velocity estimated by boundary layer heating (b), vertical velocity estimated by latent heating (c), and vertical velocity estimated by radiative processes (d). 
zonal wind $(\mathrm{u})$, meridional wind $(\mathrm{v})$, vertical velocity $(\omega)$ and heating rate: surface turbulence ( $Q_{s}$ - boundary layer heating); moisture process ( $\dot{Q}_{l}$ - latent heating); longwave radiation $\left(\dot{Q}_{l}\right)$ and shortwave radiation $\left(\dot{Q}_{s}\right)$. Adding the last two gives us the total radiative heating rate $\left(\dot{Q}_{r}\right)$. Those variables are obtained at 14 standards pressure levels $(1000 \mathrm{hPa}-100 \mathrm{hPa})$. Second, monthly SST data from the National Centers for Environmental Prediction (NCEP) SST dataset on a $2^{\circ}$ latitude by $2^{\circ}$ longitude grid are used here for the period mentioned before. These SST data were produced using a spatial interpolation method employing EOF analysis (Smith et al., 1996).

The thermodynamic energy equation in pressure coordinate is

$$
\frac{\partial \bar{T}}{\partial t}+\frac{1}{a}\left(\frac{\bar{u}}{\cos \phi} \frac{\partial \bar{T}}{\partial \lambda}+\bar{v} \frac{\partial \bar{T}}{\partial \phi}\right)+\bar{\omega}\left(\frac{\partial \bar{T}}{\partial p}-\frac{R \bar{T}}{c_{p} p}\right)=\dot{Q}
$$
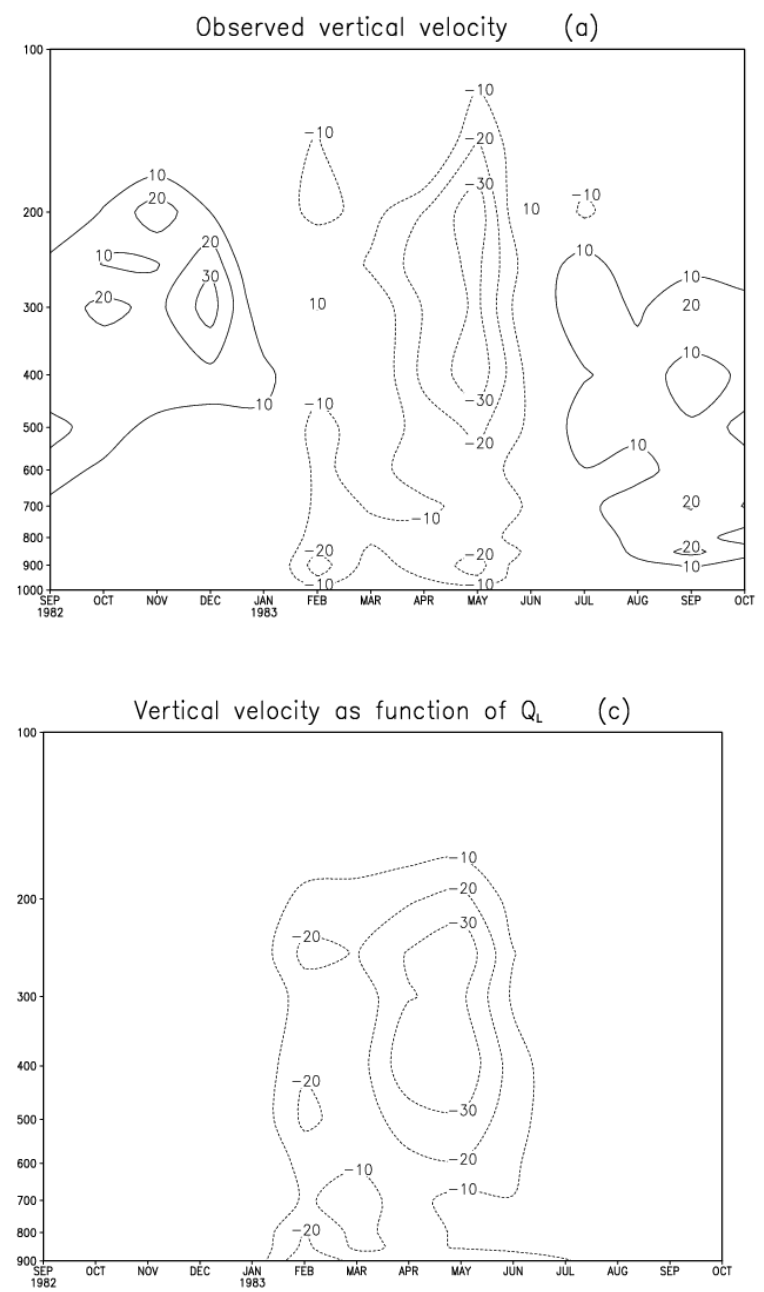

where $\mathrm{R}$ is the gas constant for dry air, $\mathrm{c}_{\mathrm{p}}$ is the specific heat of dry air at constant pressure, $p$ is the pressure in $m b$, and the diabatic heating term $\dot{Q}$ is the sum of $\dot{Q}_{s}, \dot{Q}_{l}$ e $\dot{Q}_{r}$.

Assuming that the temperature tendency is nearly zero for equatorial latitudes, from equation 1 it can be obtained

$$
\bar{\omega}=\frac{\dot{Q}-\frac{1}{a}\left(\frac{\bar{u}}{\cos \phi} \frac{\partial \bar{T}}{\partial \lambda}+\bar{v} \frac{\partial \bar{T}}{\partial \phi}\right)}{\left(\frac{\partial \bar{T}}{\partial p}-\frac{R \bar{T}}{c_{p} p}\right)}
$$

From equation 2 it can verify the role of the each heating term to vertical motion, just substituting each one in the diabatic term in equation (2). The bar quantities are for monthly mean values. The advection terms are retained in this equation because they can be significant during a strong ENSO event, as considered here.
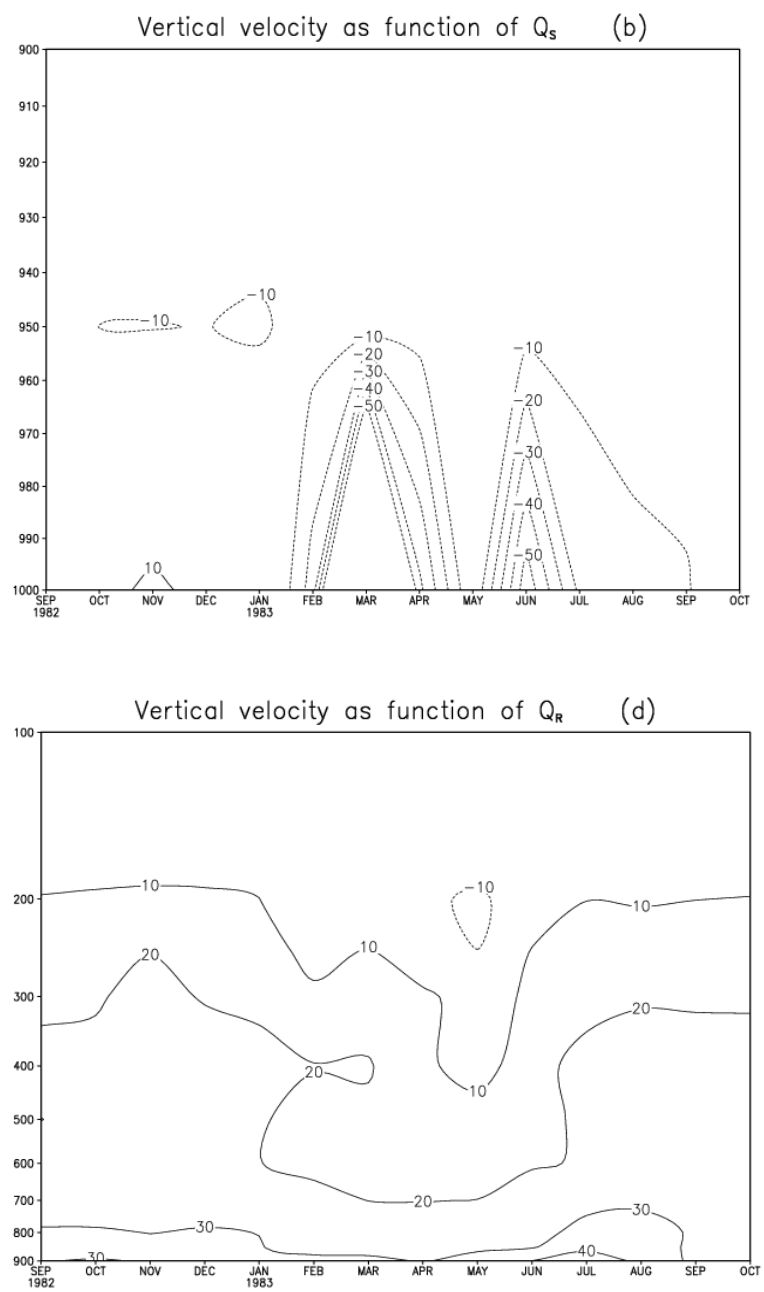

Figure - 2- Same as Fig. 1, but for $5^{\circ} \mathrm{S}, 100^{\circ} \mathrm{W}$. 


\section{RESULTS}

To emphasize the importance of the heating rate of the boundary layer as a trigger for the Walker circulation we carried out a case study involving one of the major El Niño events (1982-1983). The Figures 1 to 3 show the time-height section of vertical motion $(\omega)$ at $0^{\circ}-100^{\circ} \mathrm{W}, 5^{\circ} \mathrm{S}-110^{\circ} \mathrm{W}$ and $10^{\circ} \mathrm{S}-140^{\circ} \mathrm{W}$, respectively. The patterns are vertical velocity: observed from GEOS-1 data ( $\omega$, Figs. 1a, 2a, 3a); estimated by boundary layer heating ( $\omega$ BLH, Figs. 1b, 2b, 3b); estimated by latent heating $\left(\omega_{1}\right.$, Figs. 1c, 2c, 3c ); and estimated by radiative processes $\left(\omega_{\mathrm{r}}\right.$, Figs. 1d, 2d, 3d $)$. As can be seen from these Figures the vertical velocity field diagnosed by equation 2 (Figs. 1,2, and 3 a, c, d) suggests that this equation is a good tool for obtaining
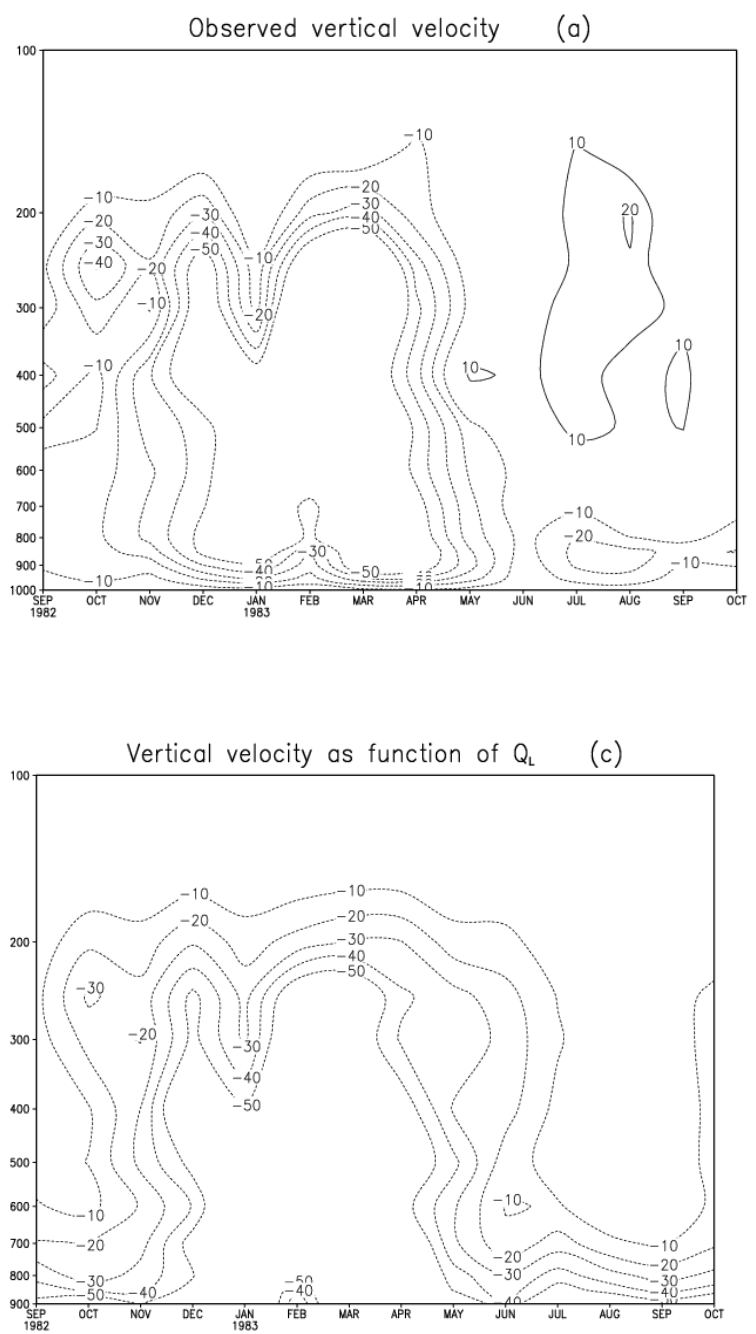

the observed vertical motions in the Walker circulation zone. From Fig. 1b it can be observed that in early January of 1983 in the eastern Pacific atmospheric movements of the air suffered a spectacular change from subsidence to ascending motions, to the abnormal Walker Circulation. This anomalous Walker circulation lasted about 7 months when normal conditions were reestablished in the eastern Pacific. We can see from Fig. 1c that there were no significant changes for vertical motions diagnosed by radiative processes.

From Fig. 1d it can be seen that before the onset of El Niño there was boundary layer cooling generating sinking motion $(\omega>0)$, which can be corroborated from Fig. 1d. By the beginning of 1983, the SST reached high values (See Fig. 4) provoking boundary layer heating and ascending motion.
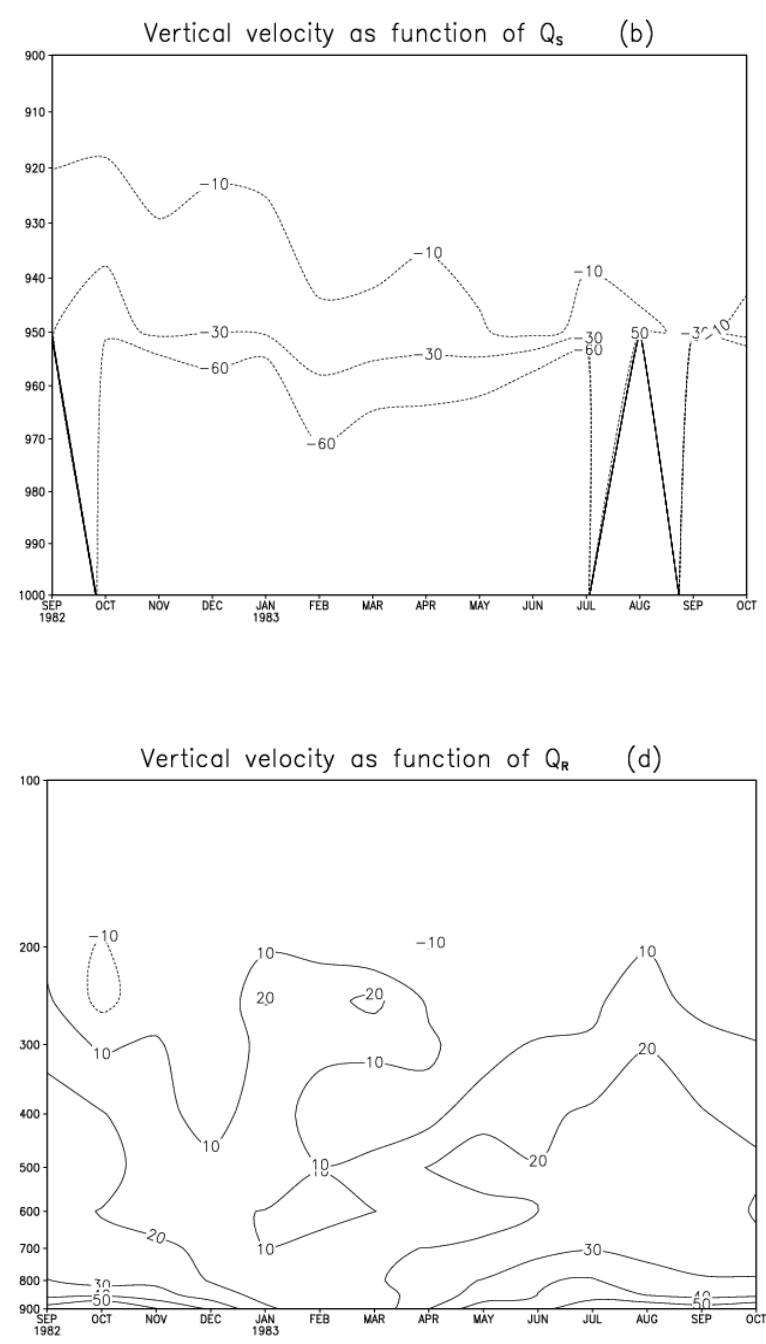

Figure -3- Same as Fig. 1, but for $10^{\circ} \mathrm{S}, 140^{\circ} \mathrm{W}$. 


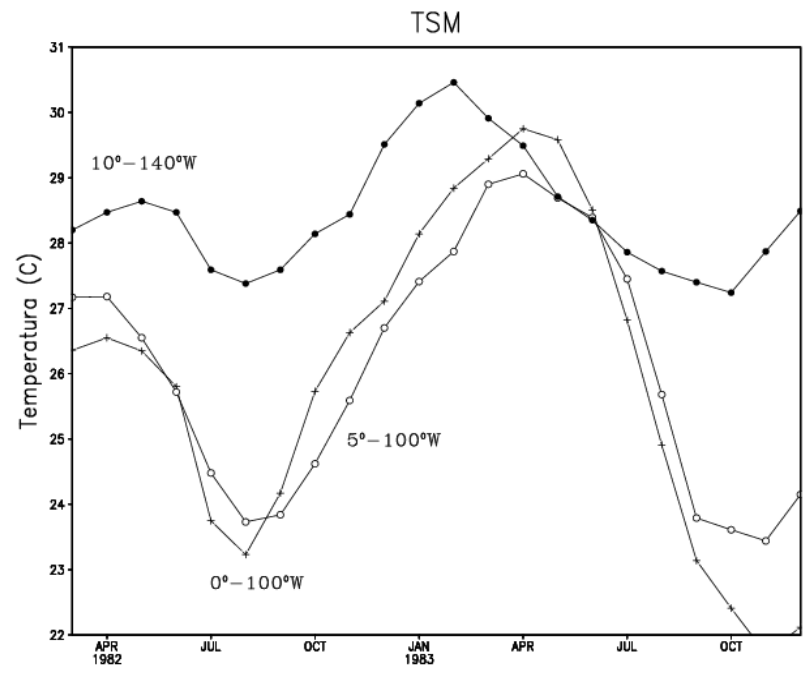

Figure 4 - Time mean evolution of the Sea Surface Temperature at equator- $100^{\circ} \mathrm{W}$ (open circles), $5^{\circ}-100^{\circ} \mathrm{W}$ (crosses), and $10^{\circ} \mathrm{S}-140^{\circ} \mathrm{W}$ (closed circles).
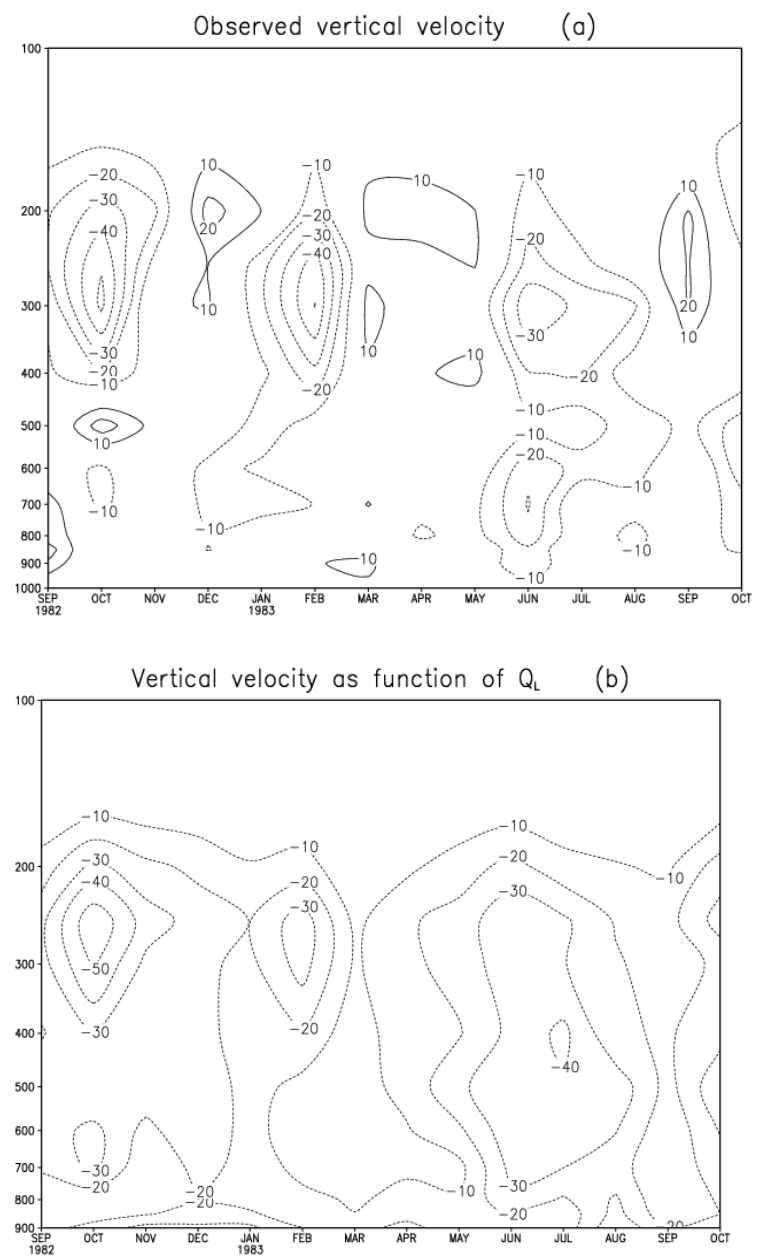

This seems to generate moist adiabatic ascent and strong ascending motion by about February 1983 as shown in Fig. 1a. As expected, the radiative cooling generated descending motion throughout the period (Fig. 1c). When the atmosphere is cooling by loosing energy to free-space the air becomes much dense and it sinks and heats the atmosphere by subsidence. The observed $\omega$ shows the descending motion at this point up to January 1983 indicating the sinking limb of the normal Walker circulation. By the beginning of 1983, the ascending motion started and continued up to July 1983. From the previous discussion it can be inferred that this changed Walker circulation with a rising limb over east Pacific was initiated with boundary layer heating over the anomalous warm pool over east Pacific. Thus, as can be seen the SST gradient has an important effect for initiating the Walker circulation, as mentioned earlier. However, the results have shown that after the boundary layer heating has initiated the Walker circulation but its maintenance is accomplished by latent heating release. Another important aspect that can be seen in Fig. $5 \mathrm{~b}$ is that the anomalous Walker Circulation subsidence
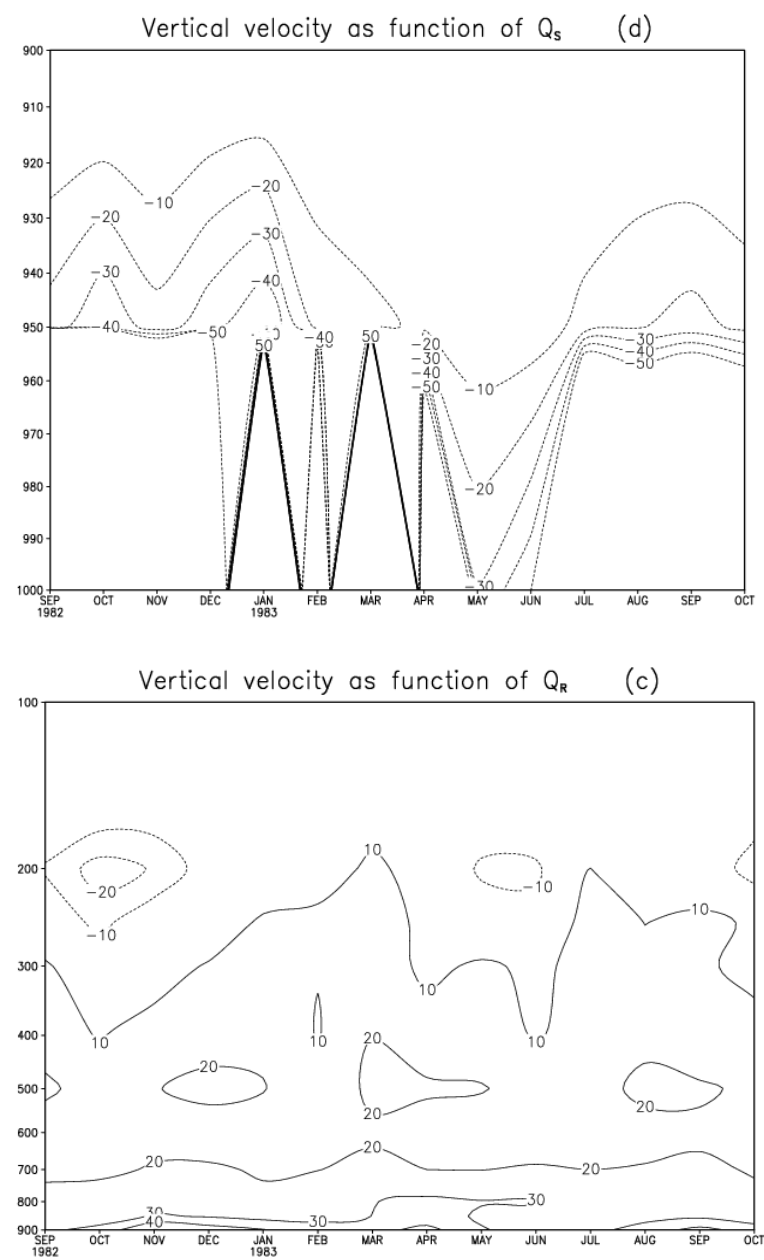

Figure 5- Same as Fig. 1, but for the equator and $160^{\circ} \mathrm{E}$. 
is created as a response to the ascent motions in the eastern Pacific. Thus, for an anomalous Walker Circulation the subsiding atmospheric air is created mainly by mass continuity, an opposite view from Yano's steady-state Walker Circulation theory.

Positive SST anomalies in central eastern Pacific establish a diabatic (sensible) heat source. This heat source will create horizontal pressure gradients causing air to converge towards the heat source at low levels and rise. The water vapor in the air will condense as it rises releasing latent heat. Thus, an atmospheric heat source is created over the SST anomaly. This intensifies further the vertical motion as seen in Fig 1a. To compensate this rising motion, sinking motion is created thus establishing the anomalous Walker circulation. This whole picture reverses creating the normal Walker circulation when the SST returns to normal low values in the east Pacific. Figs. 2 and 3 show, respectively, the changes in $\omega$ that occurred at $5^{\circ} \mathrm{S}-100^{\circ} \mathrm{W}$ and $10^{\circ} \mathrm{S}-140^{\circ} \mathrm{W}$. The characteristics of circulation in these figures are similar to those of Fig. 1.

In the original Bjerknes's concept of the Walker circulation, also the starting point of the vertical circulation is the ascending motion over the normal warm pool over west Pacific. Thus this is similar to what we suggest for the altered Walker circulation during a strong El Niño event such as 1982-1983.

\section{CONCLUSION}

Two data sets of distinct origin (NCEP and GEOS-1) were used to emphasize the important role of sensible heating in initiating the Walker Circulation during a strong El Niño episode observed in 1982-1983. The year 1982 was considered as a non-ENSO event and 1983 was characterized by an intense ENSO event. Thus, the analysis was made to investigate the mechanisms responsible to initiate the anomalous Walker Circulation over eastern Pacific. To understand how the Walker Circulation works we diagnosed from the thermodynamic equation the mean vertical motion by including diabatic parameters. Thus, we can study the role of each of the diabatic parameter in generating either ascending or descending motions.
The results showed that the altered Walker Circulation during the major El Niño event of 1982-1983 is initiated by the boundary layer heating over the relatively warm waters in the eastern Pacific. Thus it can be concluded that Bjerknes (1969) hypothesis may still be invoked as an initiating mechanism for the Walker Circulation.

\section{REFERENCES}

BJERKENS, J. Atmospheric Teleconnections from the Equatorial Pacific. Monthly Weather Review, v. 97, n.3, p. 163-172, 1969.

CORNEJO-GARRIDO, A. G. AND P. STONE. On the Heat Balance of The Walker Circulation. Journal of the Atmospheric Science v. 34, n 8, p. 1155-1162, 1977

RAO, V. B., S. R. CHAPA, AND I. F. A. CAVALCANTI. Moisture Budget in the Tropics and the Walker Circulation. Journal Geophysical Research, v. 103, n.12, p. 13713-13728, 1998.

SCHUBERT, S. D., J. PFAENDTNER, AND R. ROOD. An assimilated data set for Earth Science applications, Bulletim of American Meteorological Society, v. 74, n. 12, p. 23312342, 1993.

SMITH, T. M., R. W. REYNOLDS, R. E. LIVEZEY, AND D. C. STOKES. Reconstruction of historical sea surface temperature using empirical orthogonal functions. Journal of Climate, n. 6, v. 9, p. 1403-1420, 1996.

TAKACS, L. L., A. MOLOD, AND T. WANG. Documentation of the Goddard Earth Observing System (GEOS) General Circulation Model - Version 1. NASA Tech. Memo. 104606, $102 \mathrm{pp}, 1994$.

VEIGA, J. A. P., RAO, V. B. AND FRANCHITO, S. H. Heat and moisture budget of the Walker circulation and associated rainfall anomalies during El Niño events. International Journal of Climatology. v. 25, n. 2, p. 193-213, 2005.

YANO, J., W. W. GRABOWSKI, AND M. W. MONCRIEFF. 2002: Walker-Type Mean Circulations and Convectively Coupled Tropical Waves as an Interacting System. Journal of the Atmospheric Science, v. 59, n. 9, p. 1566-1577, 2002. 